Public Health of Indonesia

Irma, R., Widianingsih, E., \& Rasmaniar. (2020). Public Health of Indonesia: 6(3), 85-93

http://stikbar.org/ycabpublisher/index.php/PHI/index

Original Research

\title{
RELATIONSHIP OF MORINGA LEAF CONSUMPTION HABITS AND BLOOD SUGAR LEVEL IN MUNA TRIBE IN INDONESIA
}

\author{
Rita Irma, Emi Widianingsih, Rasmaniar \\ Department of Nutrition, Poltekkes Kemenkes Kendari, Sulawesi Tenggara, Indonesia
}

Received: 3 June 2020 | Accepted: 12 August 2020

DOI: https://dx.doi.org/10.36685/phi.v6i3.343

Correspondence:

\section{Rita Irma}

Jalan Jendral A.H Nasution No.G-14 Anduonohu, Kambu, Kec. Kambu, Kota Kendari, Sulawesi Tenggara 93231, Indonesia Email : ritairmasepakat@gmail.com

Mobile: 085241533003)

Copyright: (c) 2020 the author(s). This is an open-access article distributed under the terms of the Creative Commons Attribution Non-Commercial License, which permits unrestricted non-commercial use, distribution, and reproduction in any medium, provided the original work is properly cited.

\begin{abstract}
Background: In Indonesia, the prevalence of Diabetes Mellitus (DM) has increased. DM can have a significant impact on health that requires serious countermeasures. Moringa leaves have been extensively studied in terms of their efficacy in the treatment and prevention of DM.

Objective: To identify the relationship between the habit of consuming Moringa leaves and blood sugar levels of Muna tribe. Method: This study was a cross-sectional study design conducted among local people in the Muna tribe community at Gunung Jati sub-district, Kendari, Southeast Sulawesi, Indonesia. A total of 81 people was participated selected using a proportional random sampling.

Results: The average of frequency consumption of Moringa leaves among Muna tribe was one time a day, with consumption as much as 160 grams/day. The average of normal blood sugar was $103.5 \mathrm{mg} / \mathrm{dl}$. There was no relationship between age, gender, education, working status with the frequency and amount of Moringa leaf intake. Similarly, analysis of blood sugar based on characteristics, there was no relationship between gender, education, working status with blood sugar, but there was a significant relationship between age and blood sugar $(\mathrm{p}=0.00)$. There was no relationship between the frequency and amount of moringa leaf intake with blood sugar levels.

Conclusion: There was no relationship between the habit of consuming Moringa leaves both in terms of characteristics and blood sugar level among Muna people in the Gunung Jati, Kendari, Southeast Sulawesi, Indonesia.
\end{abstract}

Keywords: Moringa leaf consumption, blood sugar, Muna tribe community, Gunung Jati sub-district

\section{BACKGROUND}

Blood sugar is strongly influenced by the food. Food that we eat will be converted into sugar (glucose) and will be absorbed by the intestinal wall and circulate in the bloodstream for further with the help of insulin inserted into the cells of the body (Hartini, 2009). Normally the blood glucose level will increase but does not exceed $170 \mathrm{mg} / \mathrm{dl}$. Disease due to high blood sugar levels is called Diabetes mellitus (Sandjaja, 2010).
DM sufferers have increased every year. The Statistic Report of the International Diabetes Federation (IDF) states that in 2012 there were more than 371 million diabetics, which each year the incidence of DM increased by 3 percent or an increase of 7 million people. The American Diabetes Association reports that every 21 seconds there is one person having diabetes (Tandra, 2013). Type II diabetes mellitus will affect $439,000,000$ adults around the world in 2030. However, more than half of the Diabetes 
population is in Asia, especially in India, China, Pakistan, and Indonesia (Tandra, 2013). In Indonesia, the prevalence of DM increased from $1.1 \%$ in 2007 to $2.1 \%$ in 2013 . While in Southeast Sulawesi also increased from $1.0 \%$ in 2007 to $1.9 \%$ in 2013 despite a decrease in 2018 to $1.3 \%$ (Ministry of Health, 2007, 2013, 2018).

DM can have a significant impact on health that requires serious countermeasures. The worst impact is death; besides, DM can be a cause of various diseases such as hypertension, stroke, coronary heart disease, kidney failure, cataracts and so on. The use of complementary and alternative medicine (CAM) in general by the public is considered safer than the use of synthetic drugs, especially in patients with DM many alternative medicines use natural products to reduce blood sugar (Joeliantina, Soedirham, Agil, Qomaruddin, \& Kusnanto, 2019).

Moringa leaves are one of the native plants from various countries that have long been studied and can be used as an alternative treatment. Various studies have shown that Moringa leaves contain various substances that are beneficial for the treatment and prevention of disease (Graham, Quinn, Fabricant, \& Farnsworth, 2000; IDRIS \& ADAMU, 2018; Sampson, 2005; Talalay \& Talalay, 2001). This is because Moringa leaves are rich in nutrients and various other phytochemical compounds such as tannins, steroids, flavonoids, saponins, anthraquinones, alkaloids. Even the nutritional value is higher than some other types of food (Berkovich et al., 2013; Estiyani et al., 2017; Mbikay, 2012; Rockwood, Anderson, \& Casamatta, 2013). The results showed that Moringa oleifera water extract can cure Type 1 and 2. Diabetes Mellitus Mice that were given with moringa oleifera methanol extract decreased blood glucose significantly and increased insulin and protein levels (Divi, Bellamkonda, \& Dasireddy, 2012; Gupta et al., 2012).

Moringa leaves are consumed by many people in Indonesia, especially in Southeast Sulawesi. One of the most famous tribes in Southeast Sulawesi who likes to consume Moringa leaves is Muna tribe. The culture of consuming Moringa leaves in the Muna tribe has existed since ancient times, this plant is cultivated in almost every household by growing it in the yard (Jufri, 2014).

Gunung Jati Village is one of the villages in Kendari city and most of the Muna tribal communities live in the teak mountain area (Bahri, 2014). Almost every day the people consume moringa leaves which are processed as clear vegetables "kadada katembe". Research on blood sugar levels or the incidence of Diabetes Mellitus in the Muna ethnic group in Gunung Jati has never been done. However, based on RISKESDAS 2013 data, it shows that from 12 regencies cities in Southeast Sulawesi Province, Muna regency is one of the districts with the lowest prevalence of Diabetes after Buton district (Ministry of Health, 2013; Widiarti, 2013)

In addition, research on the effectiveness of Moringa leaves on the reduction in blood sugar is mostly still done in animal experiments. Therefore, this study aims to determine the relationship of consumption of moringa leaves (moringa oleifera) with blood sugar levels in the Muna tribe community in Gunung Jati subdistrict, Kendari City, Indonesia.

\section{METHODS}

\section{Study Design, Sample, and Setting}

This research was a descriptive-analytic study with cross-sectional study approach. The sample in this research was the Muna people who lived in Gunung Jati Village, Kendari City, Southeast Sulawesi Province, Indonesia, as the largest Muna tribe community in the City of Kendari. The number of samples as many as 81 people selected using a proportional random sampling. Citeria of sample were adults, not in a state of fasting, and not in a state of 2 hours after eating, and willing to be a participant.

\section{Measures and Data Analysis \\ Data were collected using questionnaire. The amount and types of moringa leaf consumption were measured using FFQ questionnaire and food scale. Blood sugar levels were measured using peripheral blood glucose levels with the help of Dr. Gluco's tool. Data were analyzed using chi-square test.}


Ethical Consideration

This study has obtained permission from the Southeast Sulawesi Province Research and Development Agency and the Kendari City Government, Indonesia. The involvement of participants was voluntary. Data were collected after the participant received a full explanation of the study and agreed to participate in the study by signing an informed consent. All data or information were collected and kept confidential and were only used for research purposes.

\section{RESULTS}

\section{Characteristics of Respondents}

Most of the participants were in the adult age category with an age range of 20-45 years, equal to $(75.3 \%)$. Most of the participants were women (64.2\%), with education level below Junior High School category $(50.6 \%)$. The majority of the participants were working (72.8) with professions as farmers, traders, civil servants, and employees.
Table 1. Frequency Distribution Based on Respondents'

\begin{tabular}{lcc}
\multicolumn{3}{c}{ Characteristics } \\
\hline Characteristics & n & \% \\
\hline Age (year) & & \\
$\quad$ Adult $(20-45)$ & 61 & 75.3 \\
$\quad$ Elderly $(\geq 46)$ & 20 & 24.7 \\
\hline Sex & & \\
$\quad$ Female & 52 & 64.2 \\
$\quad$ Male & 29 & 35.8 \\
\hline Education & & \\
$\quad \geq$ Senior High & 40 & 49.4 \\
$\quad$ School & 41 & 50.6 \\
$\quad \leq$ Junior High & & \\
$\quad$ School & & \\
\hline Job Status & & \\
$\quad$ Work & 59 & 72.8 \\
$\quad$ Does no work & 22 & 27.2 \\
\hline
\end{tabular}

\section{Average Moringa Leaf Consumption and}

Blood Sugar Content Samples

Table 2 shows that the average of the frequency of the consumption of Moringa leaves in the participants was one time per day with a standard deviation of 0.6 , with a maximum frequency of two times per day. The average of the amount of the consumption of Moringa was 160 grams per day with a standard deviation of 96.3 . The lowest amount of the consumption was 14 grams per day and the highest amount was 360 grams per day.

Table 2. Average of Frequency Distribution of Moringa Leaf Consumption Per Day

\begin{tabular}{lcc}
\hline Variable & Mean \pm SD & Min-Max \\
\hline Consumption of Moringa leaves (days) & $1 \pm 0.6$ & $1-2$ \\
$\quad$ Frequency (times) & $160 \pm 96.3$ & $14-360$ \\
Amount (gram) & & \\
\hline Blood sugar (mg/dl) & $103.5 \pm 15.2$ & $54-136$ \\
Normal $(<140)$ & $159.6 \pm 17.7$ & $140-193$ \\
IGT $(140-199)$ & $254.5 \pm 13.4$ & $245-265$ \\
High $(\geq 200)$ & &
\end{tabular}

Blood sugar of the participants were divided into normal, IGT and high categories. As shown in the Table 2, those with normal blood sugar has the average value of $103.5 \mathrm{mg} / \mathrm{dl}$ with a standard deviation of 15.2. The lowest blood sugar level was $54 \mathrm{mg} / \mathrm{dl}$. The participants with the IGT category had the average value of $159.6 \mathrm{mg} / \mathrm{dl}$ with a standard deviation of 17.7. Those with high blood sugar had average value of $254.5 \mathrm{mg} / \mathrm{dl}$ with a standard deviation of 13.4 , with the highest blood sugar level was $265 \mathrm{mg} / \mathrm{dl}$.

\section{Moringa Leaf Intake (Frequency) Based on Respondent Characteristics}

As shown in the Table 3, in the age category, of 61 adults, $67.9 \%$ of them consumed Moringa leaves every day, and among 20 elderlies, 23.5\% of them consumed Moringa leaves every day. The statistical analysis showed that there was no relationship of age with the frequency of intake of Moringa leaves with p-value $0.67(>0.05)$.

Based on gender, among 29 males, $32.1 \%$ of them consumed Moringa leaves every day, and of 52 females, 59.3\% consumed Moringa leaves every 
day. There was no relationship of gender and the frequency of intake of Moringa leaves with pvalue $0.69(>0.05)$.

Based on the level of education, of 41 respondents with $\leq$ junior high school, $45.7 \%$ of them consumed Moringa leaves every day, and among 40 respondents with education level $\geq$ senior high school, $45.7 \%$ of them consumed Moringa leaves every day. There was no relationship between the level of education and the frequency of Moringa leaf intake with p-value $1.00(>0.05)$.

Based on the working status, of 59 respondents who were working, $64.2 \%$ of them consumed Moringa leaves every day. Of 22 respondents who did not work, $27.2 \%$ of them consumed Moringa leaves every day. There was no relationship between work status and the frequency of Moringa leaf intake p-value 0.18 (> $0.05)$.

Table 3. Frequency of Moringa Leaf Intake Based on Respondents' Characteristics

\begin{tabular}{|c|c|c|c|c|c|c|c|}
\hline \multirow{3}{*}{ Characteristics } & \multicolumn{4}{|c|}{ Frequency of Moringa Leaves Intake/day } & \multirow{2}{*}{\multicolumn{2}{|c|}{ Total }} & \multirow{3}{*}{ p-value } \\
\hline & \multicolumn{2}{|c|}{ Every day } & \multicolumn{2}{|c|}{ Sometimes } & & & \\
\hline & n & $\%$ & $\mathbf{n}$ & $\%$ & $\mathrm{n}$ & $\%$ & \\
\hline \multicolumn{8}{|l|}{ Age (year) } \\
\hline Adult (20-45) & 55 & 67.9 & 6 & 7.4 & 61 & 75.3 & 0.67 \\
\hline Elderly $(\geq 46)$ & 19 & 23.5 & 1 & 1.2 & 20 & 24.7 & \\
\hline \multicolumn{8}{|l|}{ Gender } \\
\hline Male & 26 & 32.1 & 3 & 3.7 & 29 & 35.8 & 0.69 \\
\hline Female & 48 & 59.3 & 4 & 4.9 & 52 & 64.2 & \\
\hline \multicolumn{8}{|l|}{ Education } \\
\hline$\leq$ Junior high school & 37 & 45.7 & 4 & 4.9 & 41 & 50.6 & 1.00 \\
\hline$\geq$ Senior high school & 37 & 45.7 & 3 & 3.7 & 40 & 49.4 & \\
\hline \multicolumn{8}{|l|}{ Working status } \\
\hline Work & 52 & 64.2 & 7 & 8.6 & 59 & 72.8 & 0.18 \\
\hline Does not work & 22 & 27.2 & 0 & 0 & 22 & 27.2 & \\
\hline
\end{tabular}

Amount of Moringa Leaves (grams) per day Based on Respondents' Characteristics

Table 4 shows that, according to age group, of 61 adults, $48.1 \%$ of them consumed Moringa leaf in the amount of $\geq 160$ gram per day, and of 20 elderlies, only $18.5 \%$ of them consumed Moringa leaf in the amount of $\geq 160$ gram per day. There was no relationship between age and the amount of Moringa leaf intake with p-value $0.52(>0.05)$.

Table 4. Number of Moringa Leaf Intake (grams) Based on Respondents' Characteristics

\begin{tabular}{|c|c|c|c|c|c|c|c|}
\hline \multirow{3}{*}{ Characteristics } & \multicolumn{4}{|c|}{$\begin{array}{c}\text { Amount (Gram) of Moringa Leaves } \\
\text { Intake/day }\end{array}$} & \multirow{2}{*}{\multicolumn{2}{|c|}{ Total }} & \multirow{3}{*}{ p-value } \\
\hline & \multicolumn{2}{|c|}{$<160$} & \multicolumn{2}{|c|}{$\geq 160$} & & & \\
\hline & $\mathbf{n}$ & $\%$ & $\mathbf{n}$ & $\%$ & $\mathbf{n}$ & $\%$ & \\
\hline \multicolumn{8}{|l|}{ Age (year) } \\
\hline Adult (20-45) & 22 & 27.1 & 39 & 48.1 & 61 & 75.3 & 0.52 \\
\hline Elderly $(\geq 46)$ & 5 & 6.2 & 15 & 18.5 & 20 & 24.7 & \\
\hline \multicolumn{8}{|l|}{ Gender } \\
\hline Male & 7 & 8.6 & 22 & 27.1 & 29 & 35.8 & 0.28 \\
\hline Female & 20 & 24.7 & 32 & 39.5 & 52 & 64.2 & \\
\hline \multicolumn{8}{|l|}{ Education } \\
\hline$\leq$ Junior high school & 11 & 13.6 & 30 & 37.0 & 41 & 50.6 & 0.30 \\
\hline$\geq$ Senior high school & 16 & 19.8 & 24 & 29.6 & 40 & 49.4 & \\
\hline \multicolumn{8}{|l|}{ Working Status } \\
\hline Work & 20 & 24.7 & 39 & 48.1 & 59 & 72.8 & 1.00 \\
\hline Does not work & 7 & 8.7 & 15 & 18.5 & 22 & 27.2 & \\
\hline
\end{tabular}

Based on gender, of 29 males, $27.1 \%$ of them consumed Moringa leaves in the amount of $\geq 160$ gram per day, and of 52 females, $39.5 \%$ consumed Moringa leaves in the amount of $\geq 160$ gram per day. There was no relationship between 
gender and the amount of Moringa leaf intake with p-value 0.28 ( $>0.05)$.

Based on the level of education, of 41 respondents with education level $\leq$ junior high school, $37.0 \%$ consumed Moringa leaves in the amount of $\geq 160$ grams per day. Of 40 respondents with the education level $\geq$ senior high school, $29.6 \%$ consumed Moringa leaves in the amount of $\geq 160$ gram per day. There was no relationship between education level and the amount of Moringa leaf intake with p-value $0.30(>0.05)$.

Based on working status, of 59 respondents who were working, there were $48.1 \%$ of them consumed Moringa leaves in the amount of $\geq 160$ grams per day. Of 22 respondents who did not work, $18.5 \%$ of them consumed Moringa leaves in the amount of $\geq 160$ grams per day. There was no relationship between working status and the amount of Moringa leaf intake with p-value 1.00 $(>0.05)$.

\section{Blood Sugar Levels Based on Respondents' Characteristics}

Table 5 shows that, according to age group, of 61 adults, $67.9 \%$ of them had normal blood sugar and $7.4 \%$ had IGT. Conversely, of the 20 elderlies, $14.8 \%$ had normal blood sugar and $7.4 \%$ had IGT. There was a relationship between age and blood sugar with p-value $0.00(<.0 .05)$.

Based on gender, out of 29 males, $27.2 \%$ had normal blood sugar and $8.6 \%$ had IGT. Of 52 females, $55.5 \%$ had normal blood sugar and $6.2 \%$ had IGT. There was no relationship between gender and blood sugar with p-value 0.13 $(>0.05)$.

Table 5. Blood Sugar Levels (mg / dl) Based on Respondents' Characteristics

\begin{tabular}{|c|c|c|c|c|c|c|c|c|c|}
\hline \multirow{3}{*}{ Characteristics } & \multicolumn{6}{|c|}{ Blood Sugar (mg/dl) } & \multirow{2}{*}{\multicolumn{2}{|c|}{ Total }} & \multirow{3}{*}{ p-value } \\
\hline & \multicolumn{2}{|c|}{ Normal } & \multicolumn{2}{|c|}{ IGT } & \multicolumn{2}{|c|}{ High } & & & \\
\hline & $\mathbf{n}$ & $\%$ & $\mathbf{n}$ & $\%$ & $\mathbf{n}$ & $\%$ & $\mathbf{n}$ & $\%$ & \\
\hline \multicolumn{10}{|l|}{ Age (year) } \\
\hline Adult (20-45) & 55 & 67.9 & 6 & 7.4 & 0 & 0 & 61 & 75.3 & 0.00 \\
\hline Elderly $(\geq 46)$ & 12 & 14.8 & 6 & 7.4 & 2 & 2.5 & 20 & 24.7 & \\
\hline \multicolumn{10}{|l|}{ Gender } \\
\hline Male & 22 & 27.2 & 7 & 8.6 & 0 & 0 & 29 & 35.8 & 0.13 \\
\hline Female & 45 & 55.5 & 5 & 6.2 & 2 & 2.5 & 52 & 64.2 & \\
\hline \multicolumn{10}{|l|}{ Education } \\
\hline$\leq$ Junior high school & 30 & 37.0 & 9 & 11.1 & 2 & 2.5 & 41 & 50.6 & 0.05 \\
\hline$\geq$ Senior high school & 37 & 45.7 & 3 & 3.7 & 0 & 0 & 40 & 49.4 & \\
\hline \multicolumn{10}{|l|}{ Working status } \\
\hline Work & 48 & 59.2 & 9 & 11.1 & 2 & 2.5 & 59 & 72.8 & 0.66 \\
\hline Does not work & 19 & 23.5 & 3 & 3.7 & 0 & 0 & 22 & 27.2 & \\
\hline
\end{tabular}

Based on education level, of 41 respondents with education level $\leq$ junior high school, $37.0 \%$ had normal blood sugar and $11.1 \%$ had IGT. Of 40 respondents with a senior high school education, $45.7 \%$ had normal blood sugar and 3.7\% had IGT. There was no relationship between education level and blood sugar with $\mathrm{p}$-value 0.05 $(<0.05)$.

Based on working status, of 59 respondents who were working, $59.2 \%$ had normal blood sugar and $11.1 \%$ had IGT. Of 22 respondents who did not work, $23.5 \%$ had normal blood sugar and $3.7 \%$ with IGT. There was no relationship between working status and blood sugar with p-value 0.66 $(>0.05)$.

\section{Moringa Leaves Intake of Blood Sugar}

Table 6 shows that, based on frequency of intake, of 74 respondents who consumed Moringa leaves daily, $76.5 \%$ had normal blood sugar and $12.3 \%$ with IGT. Of 7 respondents who consumed Moringa leaves not every day, $6.2 \%$ had normal blood sugar and $2.5 \%$ had IGT. Statistical analysis showed that the value of $p=0.52(p>$ $0.05)$. There was no correlation between the frequency of Moringa leaf intake and blood sugar with p-value $0.52(>0.05)$. 
Based on the amount of intake, of 54 respondents who consumed Moringa leaves $\geq 160$ grams per day, $54.3 \%$ had normal blood sugar and $9.9 \%$ had IGT. Of 27 respondents who consumed Moringa leaves $<160$ grams per day, $28.4 \%$ had normal blood sugar and $4.9 \%$ had IGT. Statistical analysis showed that the value of $p=0.59(\mathrm{p}>$ $0.05)$. There was no relationship between the amount of Moringa leaf intake and blood sugar with p-value $0.59(>0.05)$.

Table 6. Blood Sugar Levels (mg / dl) Based on Moringa Leaves Intake

\begin{tabular}{|c|c|c|c|c|c|c|c|c|c|}
\hline \multirow{3}{*}{ Moringa Leaves Intake } & \multicolumn{6}{|c|}{ Blood Sugar (mg/dl) } & \multirow{2}{*}{\multicolumn{2}{|c|}{ Total }} & \multirow{3}{*}{ p value } \\
\hline & \multicolumn{2}{|c|}{ Normal } & \multicolumn{2}{|c|}{ IGT } & \multicolumn{2}{|c|}{ High } & & & \\
\hline & $\mathbf{n}$ & $\%$ & n & $\%$ & $\mathbf{n}$ & $\%$ & n & $\%$ & \\
\hline Frequency & & & & & & & & & \\
\hline Every day & 62 & 76.5 & 10 & 12.3 & 2 & 2.5 & 74 & 91.4 & 0.52 \\
\hline Sometimes & 5 & 6.2 & 2 & 2.5 & 0 & 0 & 7 & 8.6 & \\
\hline Amount (gram/day) & & & & & & & 54 & 66.7 & \\
\hline$\geq 160$ & 44 & 54.3 & 8 & 9.9 & 2 & 2.5 & 27 & 33.3 & 0.59 \\
\hline$<160$ & 23 & 28.4 & 4 & 4.9 & 0 & 0 & & & \\
\hline
\end{tabular}

*) IGT = Impaired Glucose Tolerance (Prediabetes)

\section{DISCUSSION}

\section{Moringa Leaf Consumption Habits in Muna Tribe Community}

The results showed that the average of Muna tribe in Gunung Jati village who consumed Moringa leaves every day was in a frequency of 1-2 times per day. Most people also consumed Moringa leaves above the average consumption with $\geq 160$ grams per day. This amount exceeds the standard portion of vegetables for one meal that was 100 grams per one meal. Most people of Muna also have a habit of eating vegetables especially Moringa leaves which are different from how to eat vegetables in general where the vegetables are separated from the dinner plates and other side dishes, the vegetables are placed separately in a bowl for each person. Next they drink vegetable water directly from the bowl or the Muna language term "Sonde Kadada". This habit is likely to be the cause of high consumption of vegetables, especially moringa leaves in the Muna tribe in the Gunung Jati village, Southeast Sulawesi Province. Gunung Jati village area has a fairly high homogeneity of community characteristics both in terms of socio-culture, the same livelihood so that this area is used as a source of life and living space of the Muna tribe (Bahri, 2014). According to the theory, eating habits are influenced by external factors which include the natural environment, social, cultural, religious and economic; while internal factor includes an emotional connection (Khumaidi, 1989).
Consumption of Moringa Leaves Based on the Characteristics of the Muna Tribe Community The results showed no relationship between age, gender, education, and working status of the Muna tribe in Gunung Jati with the frequency and amount of moringa leaf intake. This study was almost in line with the results of another study of Fadhilah, Widjanarko, and Shaluhiyah (2018) which shows no relationship between age and gender with eating habits. The amount and frequency of eating was more related to eating habits or social culture of the Muna tribe.

As the theory explains that eating behavior is the eating habits of individuals or groups of people that are influenced by factors of tradition or sociocultural background, these eating habits cannot be changed but can change due to environmental changes (Hertog, 1983; Khumaidi, 1989; Lawrence, 1980; Ritchie, 1973). Likewise, the habit of consuming Moringa leaves in the Muna tribe in Gunung Jati village has become a tradition for generations. This is also evidenced by the presence of Moringa in almost every yard of tribal houses in Gunung Jati (Jufri, 2014).

Blood Sugar Content Based on Muna Tribe Community's Characteristics

The results of this study indicated that most of the Muna community's blood sugar in the Gunung Jati village was within normal limits, only a small proportion had a blood sugar threshold value (TGT) and only 2 people had been found to have high blood sugar. Based on the results of the study, gender, education level, and occupation 
were not related to blood sugar in the Muna community. This was in line with several other studies which also showed no relationship between sex, education level, or occupation with blood sugar or the incidence of diabetes mellitus (Isnaini \& Ratnasari, 2018; Krishnan, Cozier, Rosenberg, \& Palmer, 2010; Rahayu, Utomo, \& Setiawan, 2012).

Gender was not statistically related to blood sugar but in this study, it was found that most of the respondents were female, as well as the respondents that had high blood sugar and elderly were also found in females. This was in line with Sari and Manungkalit (2019) that the characteristics of the respondents were mostly women with advanced age and Post Prandial blood sugar level $\geq 200 \mathrm{mg}$ / dl (Hyperglycemia). The results of the Basic Health Research also showed that the incidence of DM was higher in women compared to men (Ministry of Health, 2018). In women, this age is the age that enters menopause which the menopause hormone estrogen becomes low and increases insulin resistance so that blood sugar increases.

Likewise, the level of education and employment were not related to the blood sugar of the Muna people in Gunung Jati village. It was found that more than half of the population had a low level of education. The low level of education in the Muna community was also in line with the demographic characteristics of the research results of the Elderly Diabetes in PKM Mulyorejo who found that most of the respondents were actually educated in junior high school (Sari \& Manungkalit, 2019). Most of the respondents were also workers, but this was not related to blood sugar. These results are reinforced by the results of a meta-analysis of social factors that are determinants of the prevalence of events and some risk factors for DM in the Caribbean including Obesity (BMI), metabolic syndrome, diet, smoking and physical activity (Sobers-Grannum et al., 2015). In terms of the work of the Muna tribe community in Gunung Jati, most of them worked as construction workers and port workers. Although statistically the type of work was not related to blood sugar, but most of them had blood sugar within normal limits. Basic Health Research shows that based on job characteristics, the incidence of DM in people who work as laborers was lower (8.5\%) when compared to people who worked as civil servants / military police / BUMN $(13.5 \%)$, self-employed $(11 \%)$, farmers $(12.6 \%)$ and others (11.6\%) (Ministry of Health, 2018).

In contrast, age was related to blood sugar. It shows that some respondents aged 46 years had high blood sugar. This was in line with the results of other studies that show that most respondents with diabetes mellitus aged $\geq 46$ years with an average age of 53 years, and there was a relationship between age and the incidence of diabetes mellitus (Narmawan, Syahrul, \& Erika, 2018; Rahayu et al., 2012). Basic health research also shows that the incidence of DM increases with age even though $>75$ years old and the prevalence of events begins to decrease (Ministry of Health, 2018).

According to the theory, high blood sugar as an indicator of DM can be caused by several factors, namely obesity, wrong diet, stress, and age $>40$ years. The aging process becomes one of the factors, because with age, there is a decrease in physiological function of the body which is characterized by a decrease in insulin secretion. Decreased insulin secretion results in an increase in blood glucose (Soegondo, Soewondo, \& Subekti, 2009).

\section{Moringa Leaf Intake and Blood Sugar}

The results showed that the consumption habits of Moringa leaves, both in terms of frequency and amount, were not related to the blood sugar of the Muna community in Gunung Jati. Although statistically there was no relationship, the data showed that most of them had normal blood sugar. A previous study has shown that Moringa leaves contain glucomoringin, flavonoid and phenol compounds which function as antioxidants so they have excellent antidiabetic activity (AlMalki \& El Rabey, 2015). Another research also shows that regular intake of Moringa leaves can protect from oxidative damage in both normal and diabetes conditions (Jaiswal et al., 2013). However, other studies have shown that Moringa leaves do not have a significant effect on normal rat blood sugar or in type $2 \mathrm{DM}$ patients, although this study in Type 2 DM patients was carried out in the short term. However there are still 
insignificant hypoglycemic effects (Nahar, Parveen, Ara, \& Faisal, 2015; Taweerutchana, Lumlerdkij, Vannasaeng, Akarasereenont, \& Sriwijitkamol, 2017).

\section{CONCLUSION}

There was no relationship between the habits of consuming Moringa leaves both in terms of characteristics and blood sugar in the Muna tribe in the Gunung Jati sub-district of Kendari city, Southeast Sulawesi Province, Indonesia.

Acknowledgment

The author would like to thank all those who have helped this research, especially also to the Dr.Ir Trisna Astuti, MPS, and Sri Rizki, S.Gz,M.Gz who has provided direction and input in the article of this publication

References

Al-Malki, A. L., \& El Rabey, H. A. (2015). The antidiabetic effect of low doses of Moringa oleifera Lam. seeds on streptozotocin induced diabetes and diabetic nephropathy in male rats. BioMed Research International, 2015.

Bahri, A. (2014). Nilai ruang bermukim suku Muna: Kawasan Gunung Jati Kota Kendari. Yogyakarta: Universitas Gadjah Mada,

Berkovich, L., Earon, G., Ron, I., Rimmon, A., Vexler, A., \& Lev-Ari, S. (2013). Moringa Oleifera aqueous leaf extract down-regulates nuclear factor-kappaB and increases cytotoxic effect of chemotherapy in pancreatic cancer cells. BMC Complementary and Alternative Medicine, 13(1), 212.

Divi, S. M., Bellamkonda, R., \& Dasireddy, S. K. (2012). Evaluation of antidiabetic and antihyperlipedemic potential of aqueous extract of Moringa oleifera in fructose fed insulin resistant and STZ induced diabetic wistar rats: a comparative study. Asian Journal of Pharmaceutical and Clinical Research, 5(1), 67-72.

Estiyani, A., Suwondo, A., Rahayu, S., Hadisaputro, S., Widyawati, M. N., \& Susiloretni, K. A. (2017). The effect of moringa oleifera leaves on change in blood profile in postpartum mothers. Belitung Nursing Journal, 3(3), 191-197.

Fadhilah, F. H., Widjanarko, B., \& Shaluhiyah, Z. (2018). Faktor-faktor yang berhubungan dengan perilaku makan pada anak gizi lebih di sekolah menengah pertama wilayah kerja Puskesmas Poncol Kota Semarang. Jurnal Kesehatan Masyarakat (e-Journal), 6(1), 734-744.

Graham, J., Quinn, M., Fabricant, D., \& Farnsworth, N. (2000). Plants used against cancer-an extension of the work of Jonathan Hartwell. Journal of Ethnopharmacology, 73(3), 347-377.

Gupta, R., Mathur, M., Bajaj, V. K., Katariya, P., Yadav, S., Kamal, R., \& Gupta, R. S. (2012). Evaluation of antidiabetic and antioxidant activity of Moringa oleifera in experimental diabetes. Journal of Diabetes, 4(2), 164171.
Hartini, S. (2009). Diabetes siapa takut, panduan lengkap untuk diabetes. Keluarganya dan profesional medis. Jakarta: Penerbit Qanita.

Hertog, A. D., Steveren,. (1983). Perilaku Sehubungan dengan kesehatan. Indonesia: Proyek Pengembangan Penyuluhan Gizi.

Idris, S. B., \& Adamu, U. R. (2018). Phytochemicals and uses of Moringa oleifera leaves in humans and animals in Sokoto. Journal of Animal Science and Veterinary Medicine, 3(1), 30-34.

Isnaini, N., \& Ratnasari, R. (2018). Faktor risiko mempengaruhi kejadian Diabetes mellitus tipe dua. Jurnal Kebidanan dan Keperawatan Aisyiyah, 14(1), 5968.

Jaiswal, D., Rai, P. K., Mehta, S., Chatterji, S., Shukla, S., Rai, D. K., . . Watal, G. (2013). Role of Moringa oleifera in regulation of diabetes-induced oxidative stress. Asian Pacific Journal of Tropical Medicine, 6(6), 426-432.

Joeliantina, A., Soedirham, O., Agil, M., Qomaruddin, M. B., \& Kusnanto, K. (2019). A literature review of complementary and alternative medicine used among diabetes mellitus patients. International Journal of Public Health Science, 8(2), 277-286.

Jufri. (2014). Budaya konsumsi daun kelor pada suku Muna. Retrieved from: https://www.kompasiana.com/andry jufri/54f3b6b3745 513932b6c7e82/budaya-dan-kesehatan-budayakonsumsi-daun-kelor-pada-suku-muna

Khumaidi, M. (1989). Gizi masyarakat (Bahan pengajaran). Departemen Pendidikan dan Kebudayaan, Direktorat Jenderal Pendidikan Tinggi. Pusat Antar Universitas Pangan dan Gizi. Institut Pertanian Bogor, Bogor.

Krishnan, S., Cozier, Y. C., Rosenberg, L., \& Palmer, J. R. (2010). Socioeconomic status and incidence of type 2 diabetes: Results from the Black Women's Health Study. American Journal of Epidemiology, 171(5), 564-570.

Lawrence, G. (1980). Health Education planning, A diagnostic approach. USA: Mayfielt Publishing Co.

Mbikay, M. (2012). Therapeutic potential of Moringa oleifera leaves in chronic hyperglycemia and dyslipidemia: A review. Frontiers in Pharmacology, 3, 24.

Ministry of Health. (2007). Basic health research report. Retrieved from http://kesga.kemkes.go.id/images/pedoman/Riskesdas $\%$ 202007\%20Nasional.pdf

Ministry of Health. (2013). Basic health research report. Retrieved from https://www.kemkes.go.id/resources/download/general/ Hasil\%20Riskesdas\%202013.pdf

Ministry of Health. (2018). Basic health research 2018. Retrieved from https://www.kemkes.go.id/resources/download/infoterkini/hasil-riskesdas-2018.pdf

Nahar, S., Parveen, F., Ara, F., \& Faisal, F. M. (2015). Effect of pre-treatment with Moringa oleífera (Drumstick) leaves on diabetogenesis produced by alloxan in rats. Delta Medical College Journal, 3(2), 63-67.

Narmawan, N., Syahrul, S., \& Erika, K. A. (2018). The behavior of foot care in patients with type 2 diabetes mellitus: Applying the theory of planned behaviour. Public Health of Indonesia, 4(3), 129-137. 
Rahayu, P., Utomo, M., \& Setiawan, M. R. (2012). Hubungan antara faktor karakteristik, hipertensi dan obesitas dengan kejadian diabetes mellitus di Rumah Sakit Umum Daerah Dr. H. Soewondo Kendal. Jurnal Kedokteran Muhammadiyah, 1(2).

Ritchie, J. (1973). Learning better nutrition: A second study of approaches and techniques. FAO Food and Nutrition Series, (19), 1-264.

Rockwood, J., Anderson, B., \& Casamatta, D. (2013). Potential uses of Moringa oleifera and an examination of antibiotic efficacy conferred by M. oleifera seed and leaf extracts using crude extraction techniques available to underserved indigenous populations. International Journal of Phytotherapy Research, 3(2), 61-71.

Sampson. (2005). Studyng herbal remedies. New England Journal of Medicine, 353(4), 337

Sandjaja, A. (2010). Kamus gizi pelengkap kesehatan keluarga. Jakarta: PT. Kompas Media Nusantara.

Sari, N. P. W. P., \& Manungkalit, M. (2019). Predictors of post prandial glucose level in diabetic elderly. International Journal of Public Health Science (IJPHS), $8(2), 114-122$.

Sobers-Grannum, N., Murphy, M. M., Nielsen, A., Guell, C., Samuels, T. A., Bishop, L., \& Unwin, N. (2015). Female gender is a social determinant of diabetes in the Caribbean: A systematic review and meta-analysis. PloS One, 10(5), e 0126799.
Soegondo, S., Soewondo, P., \& Subekti, I. (2009). Penatalaksanaan diabetes melitus terpadu. Jakarta: Balai Penerbit FKUI.

Talalay, P., \& Talalay, P. (2001). The importance of using scientific principles in the development of medicinal agents from plants. Academic Medicine, 76(3), 238-247.

Tandra. (2013). Life healthy with diabetes, diabetes mengapa dan mengapa. Yogyakarta: Rapha Publishing.

Taweerutchana, R., Lumlerdkij, N., Vannasaeng, S., Akarasereenont, P., \& Sriwijitkamol, A. (2017). Effect of Moringa oleifera leaf capsules on glycemic control in therapy-naive type 2 diabetes patients: A randomized placebo controlled study. Evidence-Based Complementary and Alternative Medicine, 2017.

Widiarti, I., L., Prastowo, D., Siswoko, S. P., Tiku, S., Abdullah, J., \& Muh. Agusman Sorumba. (2013). Buku 2 RISKESDAS dalam angka Provinsi Sulawesi Tenggara. Indonesia: Lembaga Penerbitan Balitbangkes

Cite this article as: Irma, R., Widianingsih, R., \& Rasmaniar. (2020). Relationship of moringa leaf consumption habits and blood sugar level in Muna tribe in Indonesia. Public Health of Indonesia, 6(3), 85-93. https://dx.doi.org/10.36685/phi.v6i3.343 